\title{
サンドマスチックの温度および載荷速度に 対する強度特性試験 \\ INFLUENCE OF TEMPERATURE AND SHEARING SPEED ON STRENGTH CHARACTERISTIC OF SAND MASTIC
}

\author{
山崎智弘 1 ・澤田豊 2 ・横井敦 3 \\ Tomohiro YAMASAKI, Yutaka SAWADA and Atsushi YOKOI \\ 1正会員 博(環境） 東洋建設株式会社 名古屋支店（于460-0003 名古屋市中区錦1-17-13） \\ 2 正会員 博(農) 東洋建設株式会社 鳴尾研究所（广663-8142 兵庫県西宮市鳴尾浜1-25-1） \\ 3 東洋建設株式会社 名古屋支店（广460-0003 名古屋市中区錦1-17-13）
}

\begin{abstract}
Sand mastics are often used as impermeable materials for a waste repository. For the evaluation of the quality, compression and bending tests are carried out under a particular temperature and sheering-speed. However, in a previous study, it has been revealed that the strength characteristic of sand mastics is considerably dependent on the temperature or sheering-speed. In this study, triaxial compression tests for sand mastics were conducted in order to evaluate the strengths under various temperature or shearing-speed. From the test results, the internal friction angle was evaluated as almost zero. In addition, it was indicated that the cohesion became small with the increase of temperature or the decrease of shearing-speed. Namely, it is essential for the design to determine the strength of sand mastics according to the environmental conditions.
\end{abstract}

Key Words : Sand mastic, Strength characteristic, Temperature, Shearing speed

\section{1.はじめに}

瀝青材料（アスファルト混合物）のひとつである サンドマスチックの材料配合は, 重量比でストレー トアスファルト：石灰石粉：砂 $=16 \sim 20: 18 \sim 25$ :

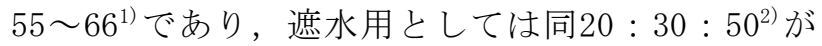
推奨されている. サンドマスチックの大きな特徴は, 遮水性に優れており, また自重により下部に発生し た隙間などに充填していく性質をもつことである. そのため，管理型処分場などにおける異質材料間の 接合部や目地部での変形追随性遮水材として利用さ れている.

しかし, サンドマスチックを護岸底面の遮水材と して, 特に滑動などの安定解析上, 土質材料として の強度評価が必要な箇所に用いる場合は, 適切に強 度設定をして設計することが望まれる。サンドマス チックの品質については, 配合設計における試験練 りや，施工時の抜き取り試験などで確認されている. これらのうち強度に関する品質試験は, 曲げ試験, 圧縮試験であり, 温度 $10^{\circ} \mathrm{C}$, 載荷速度 $20 \mathrm{~mm} / \mathrm{min}$ の 試験条件において，それぞれ $1,000 \mathrm{kN} / \mathrm{m}^{2}$ 以上であ ることが品質管理上の必要条件となっている ${ }^{1,2)}$.

ここに, サンドマスチックは高温で流動化し，ま た自重や上載荷重によりゆっくりと変形する特性を
有する材料であるため, 現場に打設したサンドマス チックの周囲温度が試験温度以上となる場合や, 試 験載荷速度よりゆっくりと変形している際の強度は, 品質試験で得られた強度より弱くなることが懸念さ れる．著者らはこのような場合の材料強度について の各種試験を実施し, 温度を $20^{\circ} \mathrm{C}$, 載荷速度を $1 \mathrm{~mm} / \mathrm{min}$ とした軸圧縮試験の結果では, サンドマ スチックの強度は品質試験における必要強度の $1 / 10$ 以下に低下寸ることや，打設層厚によっては含有砂 の沈降による材料分離が発生し, 砂含有率が小さい 表層ではさらに強度低下寸るなどの知見 ${ }^{3)}$ を示した。 本研究では, さらにサンドマスチックの強度特性 に関する知見を上積みするべく, 温度と載荷速度が サンドマスチックの強度に与える影響について, 系 統的に三軸圧縮試験を実施し評価した。

\section{2. 方法}

サンドマスチックの温度および載荷速度に対する 強度特性を調べるために三軸圧縮試験 (JGS 0521に 準拠）を実施した。試験にはストレートアスファル 卜の配合が17\%および20\%（以降，As17\%，As20\%と表 記）の供試体を用いた。供試体の配合条件を表-1に 
示す.ここに，サンドマスチックにおけるストレー トアスファルトの配合率は 16 ～20\%であるが， As $17 \%$ は土質材料として適用を念頭に施工における 材料のバラツキなどを考慮して下限值 $16 \%$ より $1 \%$ 大 きな配合とした。またAs20\%は遮水用の配合として 選定した。

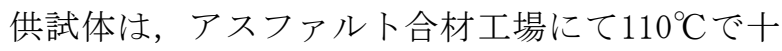
分混練したものを採取し, サミット缶 $(\phi 5 \times \mathrm{H} 10 \mathrm{~cm})$ に投入し作成した（写真-1参照）。三軸圧縮試験は 恒温室内にて実施した。供試体温度を室温各20，23， 26， $31^{\circ} \mathrm{C}$ に馴染ませ，セル内の側圧は空気圧にて約 50, $150,250 \mathrm{kN} / \mathrm{m}^{2}$ に加圧し, 載荷速度は 0.5 , $1.0,2.0 \mathrm{~mm} / \mathrm{min}$ した。 試験中には, セル内の温 度を温度計にて測定しながら, 設定温度条件下で試 験が実施できていることを確認した。試験条件を 表-2に, 試験状況を写真-2に示す.

表-1 サンドマスチックの配合

\begin{tabular}{|l|c|c|c|}
\hline \multicolumn{1}{|c|}{ 材料 } & 比重 & \multicolumn{2}{|c|}{$\begin{array}{c}\text { サンドマスチック } \\
\text { (重量比\%) }\end{array}$} \\
\hline ストレートアスフアルト(針入度60/80) & $\begin{array}{c}1.03 \\
\text { (at 15ㄷ) }\end{array}$ & 17 & 20 \\
\hline 石灰石粉 $(0.074 \mathrm{~mm}$ 未満) & 2.71 & 23 & 30 \\
\hline 砂 $(0.074 \sim 2.5 \mathrm{~mm})$ & 2.66 & 60 & 50 \\
\hline
\end{tabular}

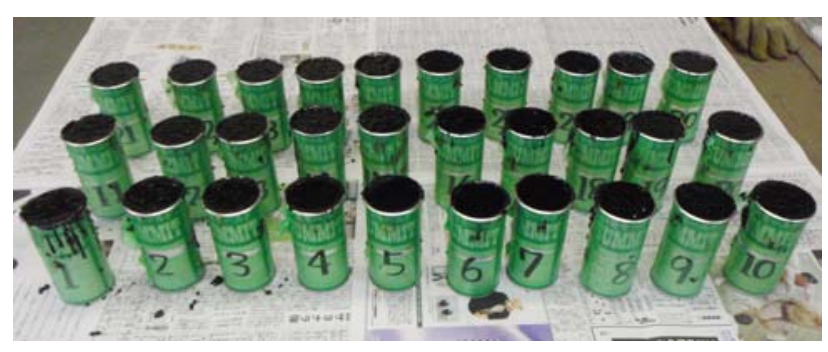

写真-1 供試体作成（サミット缶 $\phi 5 \mathrm{~cm}, \mathrm{H}=10 \mathrm{~cm}$ )

表-2 試験条件

\begin{tabular}{|c|c|c|c|c|c|}
\hline As 配合率 & 載荷速度 & \multicolumn{5}{|c|}{ 温度 $\left({ }^{\circ} \mathrm{C}\right)$} \\
\cline { 3 - 6 }$(\%)$ & $(\mathrm{mm} / \mathrm{min})$ & 20 & 23 & 26 & 31 \\
\hline \multirow{3}{*}{17} & 0.5 & $\bigcirc$ & - & $\bigcirc$ & - \\
\cline { 2 - 6 } & 1.0 & $\bigcirc$ & - & $\bigcirc$ & - \\
\cline { 2 - 6 } & 2.0 & $\bigcirc$ & - & $\bigcirc$ & - \\
\hline \multirow{3}{*}{20} & 0.5 & $\bigcirc$ & $\bigcirc$ & $\bigcirc$ & $\bigcirc$ \\
\cline { 2 - 6 } & 1.0 & $\bigcirc$ & $\bigcirc$ & $\bigcirc$ & $\bigcirc$ \\
\cline { 2 - 6 } & 2.0 & $\bigcirc$ & $\bigcirc$ & $\bigcirc$ & $\bigcirc$ \\
\hline
\end{tabular}

O: 試験実施(側圧 $50,150,250 \mathrm{kN} / \mathrm{m}^{2}$ ) - : 試験未実施

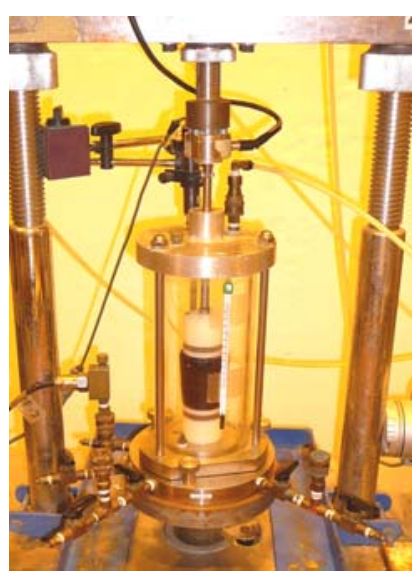

（a）試験状況

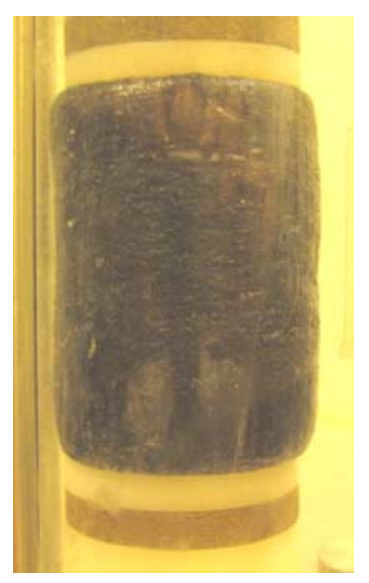

（b）試験中の供試体
写真-2 三軸圧縮試験状況

\section{3. 結果}

各試験における軸差応力ー軸ひずみ曲線を図一 1 (a) (b) (c) (d) (e) (f) に示す. As $17 \%$ で載荷速度 $2.0 \mathrm{~mm} / \mathrm{min}$ における温度 $20^{\circ} \mathrm{C}$ 側圧 $150 \mathrm{kN} / \mathrm{m}^{2}$ （図一 1 (c) 参照)，およびAs $20 \%$ で載荷速度 $2.0 \mathrm{~mm} / \mathrm{min}$ にお ける温度 $23^{\circ} \mathrm{C}$ 側圧 $150 \mathrm{kN} / \mathrm{m}^{2}$ （図-1(f) 参照）は欠測

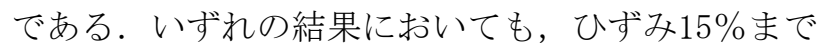
の範囲において, 応力はピーク值をとらず, 強度増 加していた.

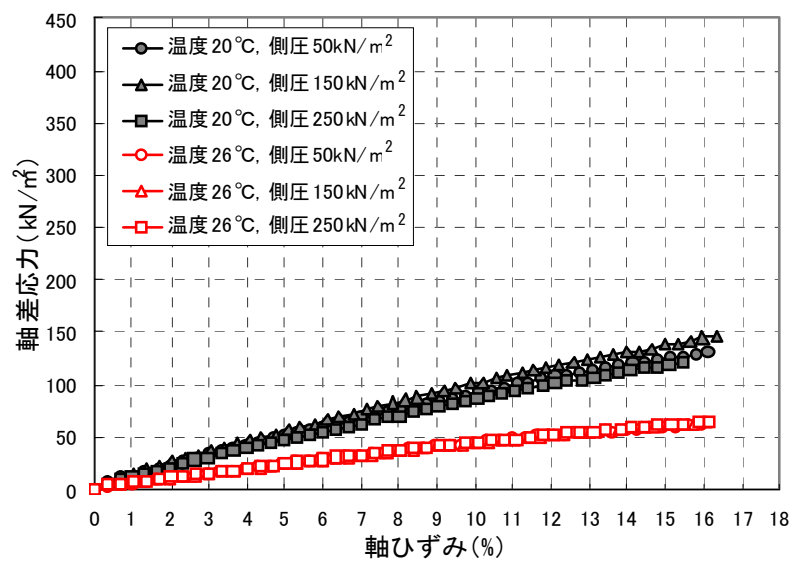

図-1（a）応力ーひずみ曲線（As17\%，載荷速度 $0.5 \mathrm{~mm} / \mathrm{min}$ )

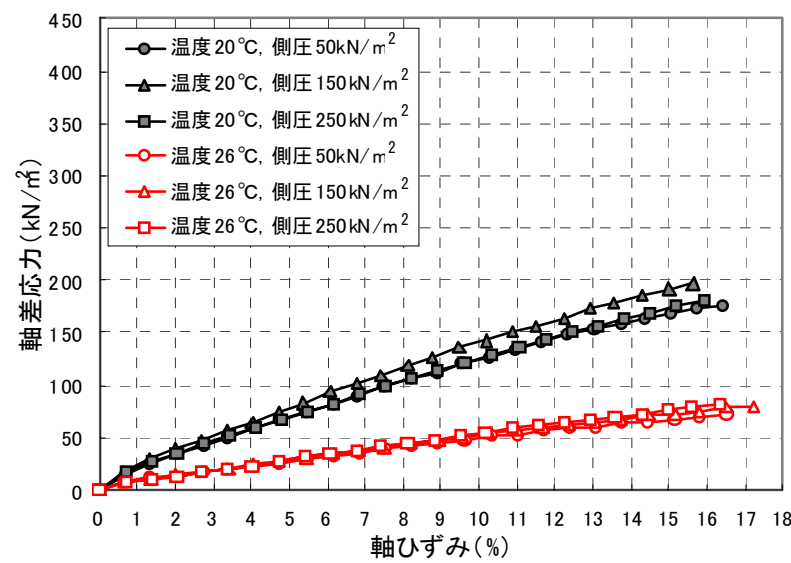

図-1 (b) 応力ーひずみ曲線（As $17 \%$ ，載荷速度 $1.0 \mathrm{~mm} / \mathrm{min}$ )

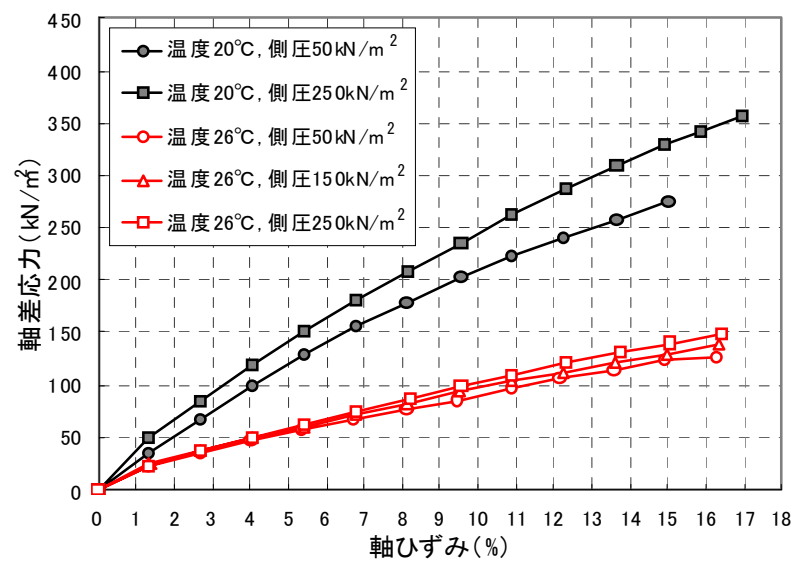

図-1 (c) 応力ーひずみ曲線（As 17\%，載荷速度 $2.0 \mathrm{~mm} / \mathrm{min}$ ） 


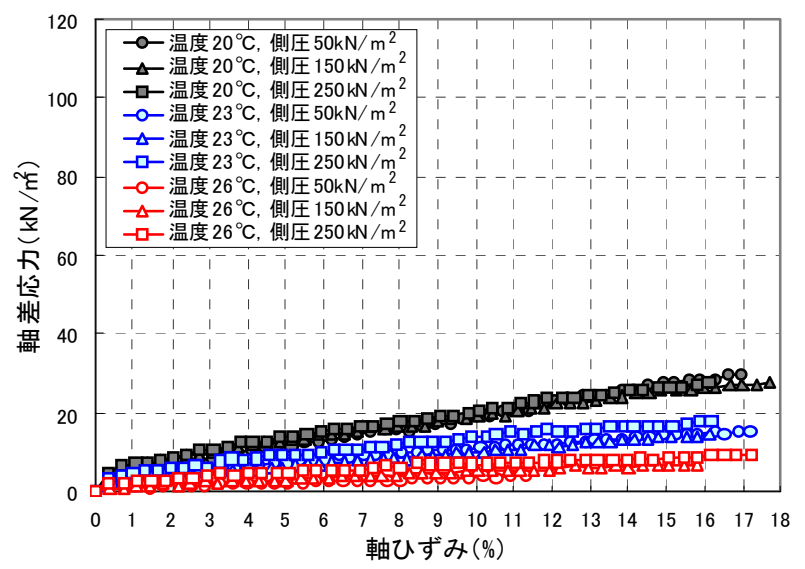

図-1 (d) 応力ーひずみ曲線（As20\%，載荷速度 $0.5 \mathrm{~mm} / \mathrm{min}$ )

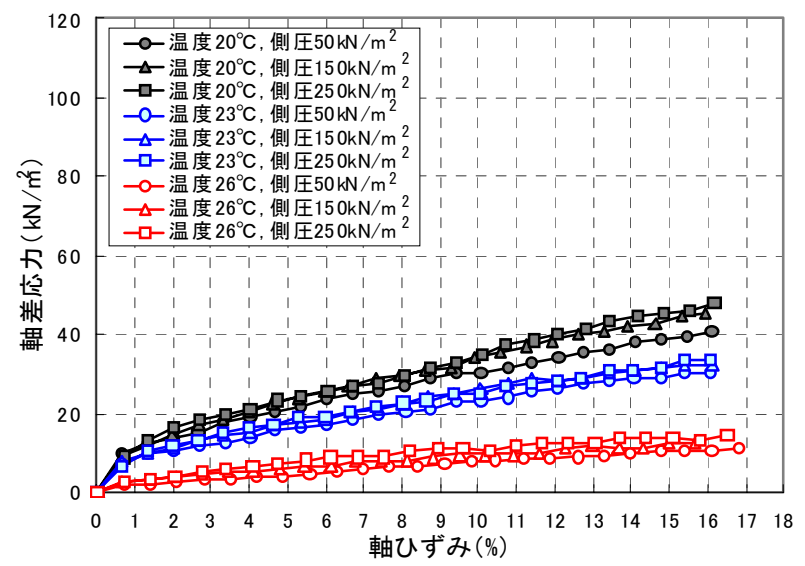

図-1（e）応力-ひずみ曲線（As20\%，載荷速度1.0mm/min）

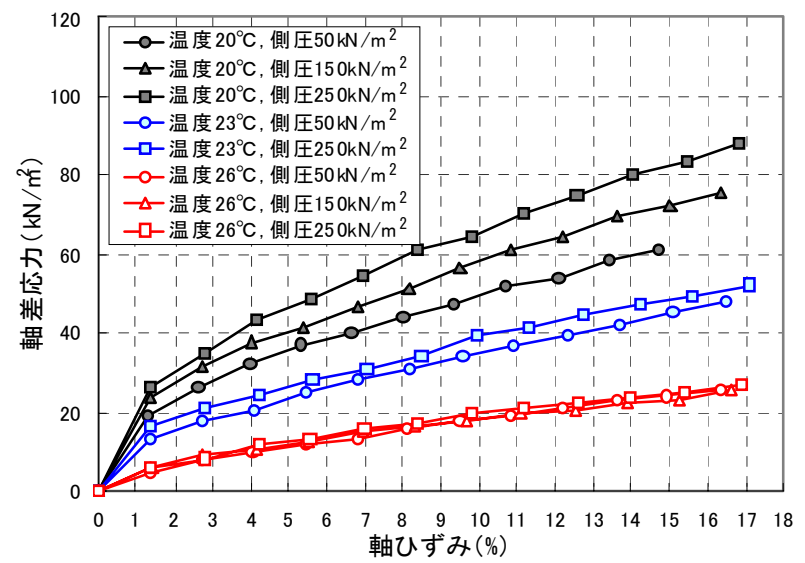

図-1（f）応力ーひずみ曲線（As20\%，載荷速度 $2.0 \mathrm{~mm} / \mathrm{min}$ )

温度および載荷速度が同じであれば，側圧を大き くしても同じひずみにおける応力は同程度の值，も しくは僅かな上昇であった。また温度が高くなると 強度は低下寸る傾向に, 載荷速度が速くなると強度 増加する傾向が確認できた．さらにAs17\% はAs20\% より高強度であった。

各試験において，ひずみ $5,10,15 \%$ におる応力を 抽出し, 温度および載荷速度ごとの内部摩擦角 $\phi$ お よび粘着力C を算定した。算定結果を表-3(a) (b) に 示す. 内部摩擦角 $\phi$ は一部のケースで負值となるよ うな，極めて $0^{\circ}$ に近い值であり，土質的には $\phi$ 材 表-3（a）内部摩擦角 $\phi$ および粘着力C (As17\%)

\begin{tabular}{|c|c|c|c|c|c|c|c|}
\hline \multirow{2}{*}{ ひずみ $(\%)$} & \multirow{2}{*}{ 温度 $\left({ }^{\circ} \mathrm{C}\right)$} & \multicolumn{3}{|c|}{ 内部摩擦角 $\phi\left({ }^{\circ}\right)$} & \multicolumn{3}{|c|}{ 粘着力C $\left(\mathrm{kN} / \mathrm{m}^{2}\right)$} \\
\cline { 3 - 8 } & & \multicolumn{1}{|c|}{ 載荷速 $(\mathrm{mm} / \mathrm{min})$} & \multicolumn{3}{|c|}{ 載荷速度 $(\mathrm{mm} / \mathrm{min})$} \\
\cline { 3 - 8 } & 0.5 & 1.0 & 2.0 & 0.5 & 1.0 & 2.0 \\
\hline \multirow{2}{*}{5} & 20.1 & -0.60 & 0.13 & 2.93 & 27.6 & 36.0 & 54.3 \\
\cline { 2 - 8 } & 25.8 & 0.03 & 0.23 & 0.68 & 12.5 & 13.8 & 26.3 \\
\hline \multirow{2}{*}{10} & 20.1 & -0.59 & 0.02 & 4.89 & 48.6 & 65.1 & 91.3 \\
\cline { 2 - 8 } & 25.8 & -0.02 & 0.59 & 1.62 & 22.6 & 24.4 & 43.1 \\
\hline \multirow{2}{*}{15} & 20.1 & 0.93 & 0.71 & 7.36 & 65.2 & 86.2 & 113.5 \\
\cline { 2 - 8 } & 25.8 & 0.26 & 1.21 & 2.35 & 29.8 & 32.6 & 57.0 \\
\hline
\end{tabular}

表-3(b) 内部摩擦角 $\phi$ および粘着力C (As20\%)

\begin{tabular}{|c|c|c|c|c|c|c|c|}
\hline \multirow{3}{*}{ ひずみ $(\%)$} & \multirow{3}{*}{ 温度 $\left({ }^{\circ} \mathrm{C}\right)$} & \multirow{2}{*}{\multicolumn{3}{|c|}{$\begin{array}{l}\text { 内部摩擦角 } \phi\left(^{\circ}\right) \\
\text { 載荷速度 }(\mathrm{mm} / \mathrm{min})\end{array}$}} & \multirow{2}{*}{\multicolumn{3}{|c|}{$\begin{array}{l}\text { 粘着力C }\left(\mathrm{kN} / \mathrm{m}^{2}\right) \\
\text { 載荷速度 }(\mathrm{mm} / \mathrm{min})\end{array}$}} \\
\hline & & & & & & & \\
\hline & & 0.5 & 1.0 & 2.0 & 0.5 & 1.0 & 2.0 \\
\hline \multirow{4}{*}{5} & 20.1 & 0.33 & 0.36 & 1.37 & 5.5 & 10.3 & 16.3 \\
\hline & 23.0 & 0.28 & 0.32 & 0.34 & 3.2 & 7.7 & 11.5 \\
\hline & 25.9 & 0.39 & 0.47 & 0.27 & 1.0 & 1.8 & 5.1 \\
\hline & 31.0 & -0.06 & -0.20 & -0.52 & 1.1 & 2.5 & 4.7 \\
\hline \multirow{4}{*}{10} & 20.1 & 0.24 & 0.67 & 2.29 & 9.2 & 14.6 & 21.9 \\
\hline & 23.0 & 0.39 & 0.29 & 0.61 & 4.8 & 11.6 & 16.6 \\
\hline & 25.9 & 0.43 & 0.44 & 0.21 & 1.7 & 3.5 & 8.8 \\
\hline & 31.0 & -0.16 & -0.39 & -0.82 & 2.0 & 3.9 & 7.1 \\
\hline \multirow{4}{*}{15} & 20.1 & -0.16 & 1.05 & 2.74 & 13.7 & 18.3 & 27.4 \\
\hline & 23.0 & 0.38 & 0.43 & 0.48 & 6.5 & 14.2 & 21.7 \\
\hline & 25.9 & 0.27 & 0.52 & 0.08 & 3.0 & 4.7 & 11.7 \\
\hline & 31.0 & -0.20 & -0.58 & -1.14 & 2.5 & 5.1 & 9.1 \\
\hline
\end{tabular}

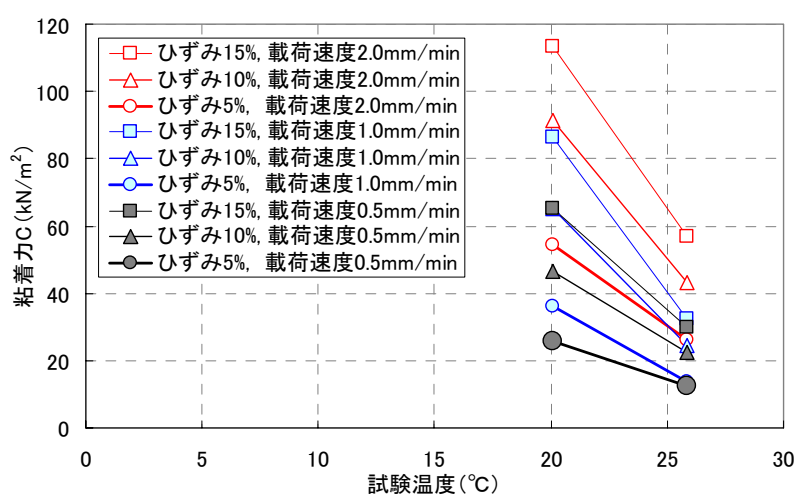

図-2（a）粘着力C（As17\%）

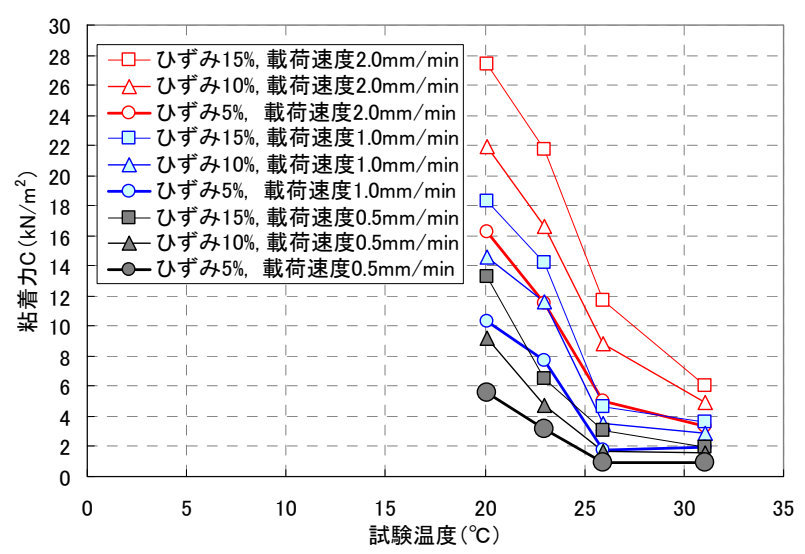

図-2 (b) 粘着力C（As20\%）

としては評価しにくい.

さらに, 粘着力C について結果を整理した. 結果 の整理において, 内部摩擦角 $\phi$ が負值となるケース については， $\phi=0$ としてC を再算出した. 温度およ び載荷速度ごとの粘着力C を図-2(a) (b)に示す. 温 度が高くなるほど, また載荷速度が遅くなるほじ, さらにひずみが小さいほど, 粘着力C は小さくなる 傾向があった。As $20 \%$ における温度 $26^{\circ} \mathrm{C}$ と $31^{\circ} \mathrm{C}$ 粘 
着力C を比較すると, ひずみが小さく, 載荷速度が 遅い条件においては, 同程度の強度であった（図一 2(b) 参照) .

\section{4. 考察}

サンドマスチックの品質試験における圧縮強度の 基準值 $\mathrm{q}_{\mathrm{u}}$ は $1,000 \mathrm{kN} / \mathrm{m}^{2}$ 以上（温度 $10^{\circ} \mathrm{C}$, 載荷速度 $20 \mathrm{~mm} / \mathrm{min}$ ）であるが，本試験条件ではAs $17 \%$ の圧縮 強度 $\mathrm{q}_{u}(=2 \times \mathrm{C})$ は, $20 \sim 240 \mathrm{kN} / \mathrm{m}^{2}$ と基準值の約 1/4以下であり, As $20 \%$ の圧縮強度 $\mathrm{q}_{\mathrm{u}}$ は2 2 60 $\mathrm{kN} / \mathrm{m}^{2}$ と同約 $1 / 15$ 以下であった。 また温度が高く, 載荷速 度が遅い場合, 強度低下寸ることが明らかとなった。

図-1および表-3に示すとおり, サンドマスチック は側圧の増加に伴う強度増加が僅かなことから, 土 質強度として設定する場合は， $\phi$ 材ではなく, 粘性 材料として粘着力Cで評価することが適当と考えら れる. サンドマスチックの粘着力Cを設定する場合 には, サンドマスチック設置場所の環境温度最大值 や，許容できるひずみ量を考慮する必要がある。サ ンドマスチックを陸上に設置する場合は，夏期の気 温が $30^{\circ} \mathrm{C}$ 以上に達する場合があり, 水中に設置する 場合においても水温が $25^{\circ} \mathrm{C}$ 超える場合がある。温 度環境を $26^{\circ} \mathrm{C}$ と想定した場合，許容ひずみを $5 \%$ と する場合, 図-2 (a) (b)の試験結果より, 粘着力Cは As $17 \%$ で約 $10 \mathrm{kN} / \mathrm{m}^{2}$, As $20 \%$ で約 $1 \mathrm{kN} / \mathrm{m}^{2}$ と設定する ことが示唆できる.As17\%の方が高強度となる理由 は, 配合されたストレートアスファルトの体積が少 なく, 砂含有量が大きく, サンドマスチック内部に おいて砂同士のせん断抵抗が大きくなることが挙げ られる。

以上より, 遮水性を確保する場合は砂含有量の相 対的に少なく, 遮水材としての既往知見 $4,5,5), 7$ が 豊富なAs20\%が変形しやすく適切な配合と考えられ る。しかしながら材料に強度が要求される場合につ いては砂含有量の多いAs17\%が施工時の材料分離の 傾向も小さく3), 適切な配合と考えられる.

次に, 品質試験の実施において, 温度とは別に配 合の違いによる強度影響を明らかにすることを目的

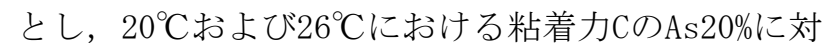
するAs $17 \%$ の比を図-3に示す． $20^{\circ} \mathrm{C}$ におる粘着力 比は，約 $3 \sim 5$ であるが, $26^{\circ} \mathrm{C}$ では約 $5 \sim 13$ であった。 高温ほどまた載荷速度が遅いほど配合による粘着力 Cの比が大きい傾向であった，逆に，低温になると 配合や載荷速度の違いによる差は小さくなる傾向に ある。品質試験時の温度は $10^{\circ} \mathrm{C}$ かつ載荷速度 20 $\mathrm{mm} / \mathrm{min}$ と比較的低温であり, 載荷速度が速いため, 配合が規定の範囲内で異なっていても，一律の基準 值で管理できると考えられる.

さらにアスファルト合材工場にて日あたり約 $100 \mathrm{t}$ 前後のサンドマスチック（配合は表-1と同じ）を製 造した際に，その品質確認として抜き取った延45日 間の供試体について公的機関で実施した密度および

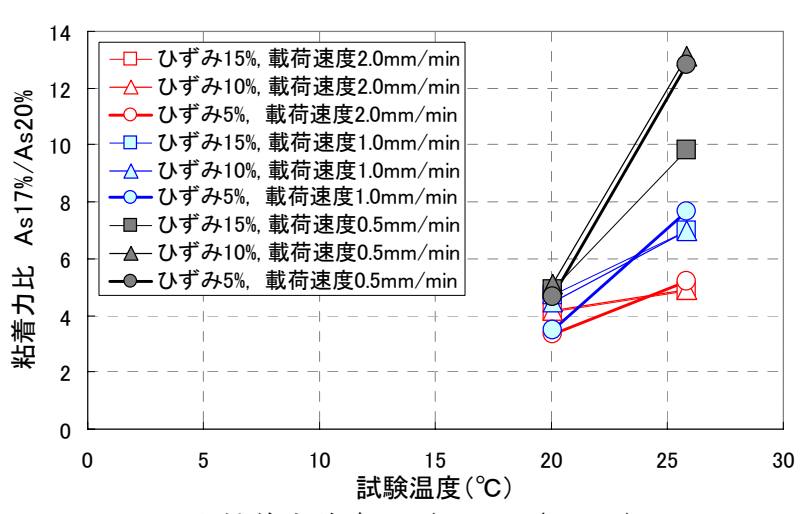

図-3 粘着力強度比（As17\%/As20\%）

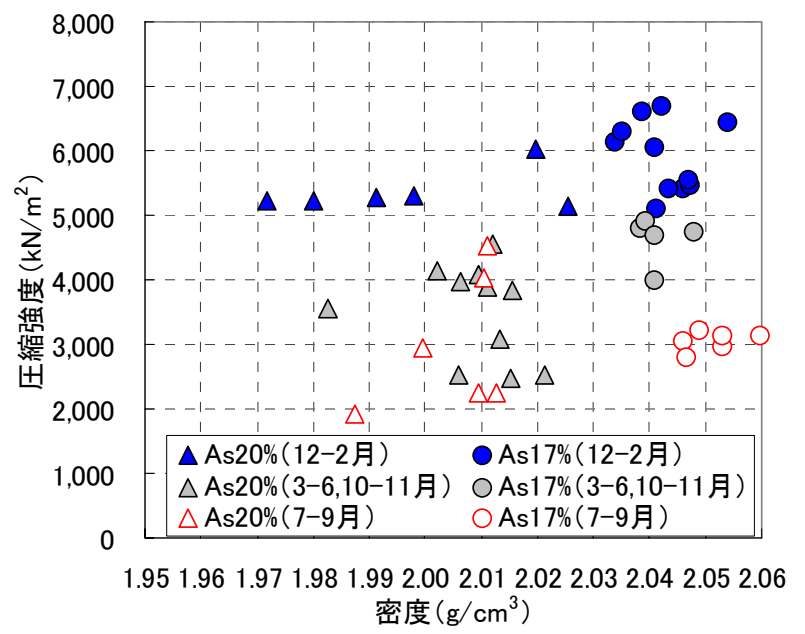

図-4 サンドマスチック密度と圧縮強度

圧縮試験（温度 $10^{\circ} \mathrm{C}$, 載荷速度 $20 \mathrm{~mm} / \mathrm{min}$, 舗装調 查・試験法便覽 ${ }^{8)}$ ) の結果を図-4に示寸。密度は As20\%よりAs17\%の方が大きかった。これは比重の大 きな石灰石粉と砂の含有量が多いためである. 密度 はAs17\%およびAs20\%とも要求品質規格值である1.95 $\mathrm{g} / \mathrm{cm}^{3}{ }^{1)}$ を上回っており，また配合ごとの標準偏差 は約 $0.01 \mathrm{~g} / \mathrm{cm}^{3}$ であり，実施工においてバラツキ の少ないサンドマスチックがアスファルト合材工場 より供給されたことが確認できた。一方で, 圧縮強 度については定性的には砂含有量が大きいほど，つ まり密度が大きいほど圧縮強度は大きくなると考え られるが，図-4の結果はその限りではない。圧縮強 度の標準偏差はAs $17 \%$ で約 $600 \mathrm{kN} / \mathrm{m}^{2}$ であるのに対 し，As20\%では約1, $200 \mathrm{kN} / \mathrm{m}^{2}$ であり，As20\%の方が バラッキは大きい。図中には夏季（7-9月）と冬季 （12-2月）とそれ以外の期間に分けて圧縮強度を示 している. 相対的に夏季の強度が弱く冬季が強い傾 向が確認できる.これは試験手順に起因することが 考えられる.つまり, 試験温度が $10^{\circ} \mathrm{C}$ と規定されて いるため, 試験に用いる供試体は恒温庫や水浴によ り $10^{\circ} \mathrm{C}$ 環境下に馴染ませた後, すみやかに室内の試 験機にかけられる。ここに, 試験機のある室内の温 度を $10^{\circ} \mathrm{C}$ とすることが困難な場合, 供試体温度は試 験終了までの経過時間とともに上昇することが考え られ, この場合, 圧縮強度は $10^{\circ} \mathrm{C}$ 想定時より軟弱に なることが懸念される.この影響がAs $20 \%$ 方が大 
きかったものと考えられる。いずれの試験結果にお いても圧縮強度の要求品質規格值である 1,000 $\mathrm{kN} / \mathrm{m}^{2}$ を上回っているため, 品質管理上の問題は生 じない。しかし，本論文にてサンドマスチックの強 度が温度の影響を受けることを明らかにした。よっ て意義のある品質試験を実施するためには, 試験前 の供試体温度のみならず, 試験中の供試体温度につ いても把握し評価することや，サンドマスチックの 比熱を考慮して一定の短時間内に試験を実施するな どの試験時の規定を設けることが必要と考える.さ らに一歩踏み込むならば, 試験時の温度環境が $10^{\circ} \mathrm{C}$ に維持できない場合を鑑み, 試験温度を $20^{\circ} \mathrm{C}$ とする 強度基準值を設定することや, $20^{\circ} \mathrm{C}$ と $10^{\circ} \mathrm{C}$ の強度換 算係数を配合ごとに設定することが必要と思われる。

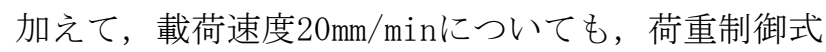
の試験に代替するなど, 再考する必要性が示唆でき る.

なお，As17\%およびAs20\%の供試体を用いた透水試 験（150kPaにて24時間加圧後10分間計測，舗装調 查・試験法便覧8) $)$ を実施した結果，いずれも透水 しなかった。したがって, As17\%においても遮水性 を確保した材料であることが確認できた（写真-3参 照）.

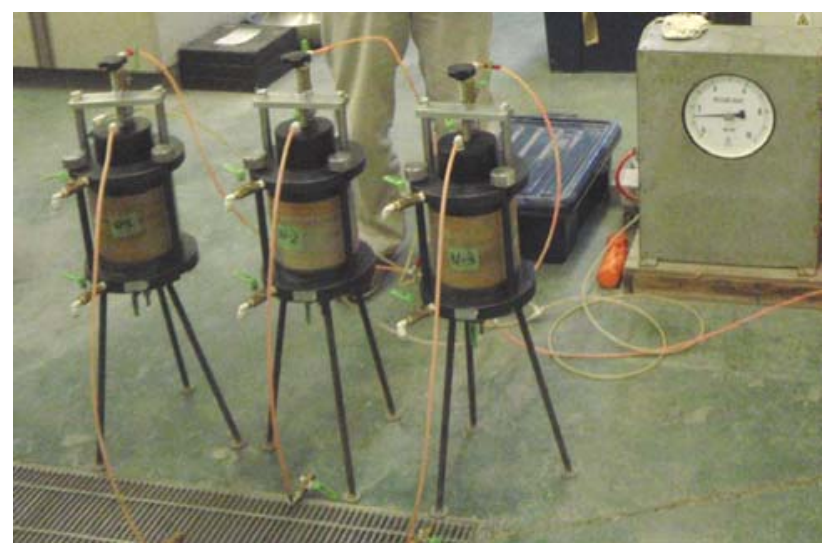

写真-3 As17\%における透水試験状況

\section{5. 結論}

陸上や水中における環境温度のうち比較的高温域 でのサンドマスチックの強度について定量的な評価
を行うことを目的に，三軸圧縮試験を実施した。品 質試験条件下での基準值と比較して, 温度が高いほ ど，また載荷速度が遅いほど強度は小さくなる傾向 があることが確認できた。 したがって，サンドマス チックを強度材料として設計・施工する場合は, 品 質試験条件下での強度試験值ではなく, 施工する環 境条件に応じた強度設定を行う必要がある。

課題としては, 品質確認試験条件や評価方法につ いて見直しすることに加え, As17\%における変形追 随機能としての品質について知見を蓄積することが 挙げられる.

謝辞：本試験の実施にあたり，供試体の作成および 品質確認試験の準備には前田道路㑣衣浦合材工場お よび(株)NIPP0知多合材工場の御協力をいただいた. ここに謝意を表す。

\section{参考文献}

1）国土交通省港湾局監修，(社)日本港湾協会：港湾の施設 の技術上の基準・同解説，pp. 451-456，2007.7.

2）海洋アスファルト工法研究会 : アスファルトマスチッ ク技術マニュアル，p. 19, 2010.

3）山崎智弘, 横井敦, 澤田豊 : アスファルト混合物の温 度および変位速度に対する強度特性試験, 海洋開発論 文集, 26, pp. 1029-1034, 2010.

4) 上杉忠男, 中川純一, 鵜飼亮行, 石本健治, 土屋美和, 中野浩：異種材料を組み合わせた廃書物埋立護岸の遮 水構造の実験的検討, 海洋開発論文集, 21, pp. 837$842,2005$.

5）中野浩, 伊坂健二, 伊藤隆彦, 和木多克, 野々田充: 軟弱な捨石マウンド上に水中打設されたアスファルト マスチック層の変形追随・遮水性に関する実験的検討, 土木学会年次学術講演会講演概要集第 7 部, 58, pp. 289-290, 2003.

6) 星野太, 和木多克, 中野浩, 伊藤隆彦, 野々田充: ア スファルトマスチックの変形追随性の実験的検討, 土 木学会年次学術講演会講演概要集第 7 部, 58, pp. 313314, 2003.

7）伊藤隆彦, 伊坂健二, 野々田充, 中野浩, 和木多克: 水中打設したアスファルトマスチックと各種接合部の 透水性に関寸る実験的検討, 土木学会年次学術講演会 講演概要集第 7 部, 58, pp. 317-318, 2003.

8）（社）日本道路協会：舗装調查·試験法便覧，H19.6. 